\title{
Structure Design and Simulation Analysis Floating and Sinking Inverted Siphon
}

\author{
Xie Xiangzan \\ Hunan Urban Construction College \\ Xiangtan, China \\ 42831966@qq.com
}

\begin{abstract}
The engineering big punch inverted siphon is located in coastal tidal areas of Doumen country, Gangdong province, and engineering use hinged assembly structure, method of construction using prefabricated Floating. First the pipe body is prefabricated, then floating and sinking into place, and then joints and import and export of construction. Static analysis of inverted siphon is the foundation of design and construction of inverted siphon, through static analysis of inverted siphon, we can get the change law of stress and displacement of the inverted siphon. The inverted siphon structure is thin-walled concrete structure, structural analysis is of great significance to study the safety the inverted siphon structure. Inverted siphon is an important diversion structures, using the finite element calculation software to carry out stress analysis of big punch Inverted, and obtain the stress and the deformation distribution on the inverted siphon pipe during operation. The results show that the big punch inverted siphon is a reasonable structure and meet the design requirements.
\end{abstract}

Keyword-Floating and sinking; Inverted siphon; Structure design; Finite element analysis; Stress distribution.

\section{ENGINEERING SITUATION}

The engineering big punch inverted siphon is located in coastal tidal areas of Doumen country, Gangdong province, and engineering use hinged assembly structure, method of construction using prefabricated Floating[1]. First the pipe body is prefabricated, then floating and sinking into place, and then joints and import and export of construction. Big punch inverted siphon design flow is $3.0 \mathrm{~m}^{3} / \mathrm{s}$, design head $6.55 \mathrm{~m}$, pipeline length of $51.8 \mathrm{~m}$, hole with a square cross-section, pore size $1.35 \mathrm{~m} \times 1.35$ $\mathrm{m}$, the pipe wall thickness $0.18 \mathrm{~m}[2]$.

\section{Calculation Model}

The big punch inverted siphon uses reinforced concrete materials, and concrete strength grade is C20, elastic modulus $E_{1}=25.5 \mathrm{GPa}$, poisson ratio $\mu_{1}=0.167$ [3-4], bulk density $\gamma_{1}=25 \mathrm{kN} / \mathrm{m}^{3}$. The steel strength grade is II, elastic modulus $E_{s}=200 \mathrm{GPa}$, poisson ratio $\mu_{s}=0.28$. The foundation of inverted siphon is mud or silt [5-6], using the dredger excavating the foundation. Material compression modulus is $E_{2}=18$ $\mathrm{MPa}$, poisson ratio $\mu_{2}=0.32$.
Establishing Big punch Inverted computational model, using an 8-node isoparametric block element SOLID45 simulated soil, using 8-node isoparametric block element SOLID65 [7-8] simulation inverted siphon pipe, this unit is a concrete simulation dedicated unit, and you can set the volume ratio of reinforcement in all directions on the concrete structure. The bottom of river inverted siphon cover thickness is $1.2 \mathrm{~m}$, under the bed thickness $18 \mathrm{~m}$, channel width $14 \mathrm{~m}$, and the size of the entire calculation model for the inverted siphon along its direction take 40m, Yokogawa direction $28 \mathrm{~m}$, vertical direction $30 \mathrm{~m}$. Analog range of the model is $40 \mathrm{~m} \times 28 \mathrm{~m} \times 30 \mathrm{~m}$ [9-10].

At the action of 6.55 meters hydraulic head, we take out three typical sections at the inverted siphon which is located on the bottom of 14 meters wide river channel. The three typical section, each 3.5 meters along the direction of flow, are defined as the section of 1-1, 2-2 and 3-3. At the same time, the paths from 1 to 7 are defined at the middle roof of inverted siphon, the boundary of the roof and the curb plate(2 line), the middle of the curb plate, the boundary of the curb plate and the bottom plate(2 line) and the middle of the bottom plate. In the following, the distribution of stress and strain in those sections and paths will be presented.

\section{RESULT ANALYSIS}

\section{A. Stress Analysis}

Table 1 shows the variation of the circumferential stress on the critical points of the path. As can be seen from Table 1, the circumferential stress on the critical points of the path are small, the circumferential stress on the path $1,4,7$ smaller than the stress values on the other path, which is mainly due to generated stress concentration on other path, and from the end to the middle, the value of circumferential stress is first and then decrease. As can be seen from Fig.1 and Fig.2, the first principal stress on inverted siphon pipe top, bottom and sides is small and uniform distribution, but the first principal stress is slightly larger in the angle of the inverted siphon pipe cross-section and the stress distribution is more complex. As can be seen from Fig.3 and Fig.4, the circumferential stress distribution of inverted siphon pipe is similar to the first principal stress distribution. 
TABLE I. CIRCUMFERENTIAL STRESS ON THE KEY POINTS OF EACH PATH（MPA）

\begin{tabular}{|c|c|c|c|c|c|c|c|c|}
\hline \multirow{2}{*}{ location } & \multicolumn{7}{|c|}{ key points } \\
\cline { 2 - 9 } & $\mathbf{1}$ & $\mathbf{2}$ & $\mathbf{3}$ & $\mathbf{4}$ & $\mathbf{5}$ & $\mathbf{6}$ & $\mathbf{7}$ & $\mathbf{8}$ \\
\hline Path 1 & 0.150 & 0.225 & 0.223 & 0.137 & 0.224 & 0.224 & 0.224 & 0.150 \\
\hline Path 2 & 0.256 & 0.140 & 0.161 & 0.150 & 0.152 & 0.161 & 0.158 & 0.260 \\
\hline Path 3 & 0.202 & 0.157 & 0.166 & 0.146 & 0.150 & 0.161 & 0.161 & 0.241 \\
\hline Path 4 & 0.124 & 0.220 & 0.217 & 0.115 & 0.217 & 0.216 & 0.218 & 0.122 \\
\hline Path 5 & 0.259 & 0.154 & 0.150 & 0.131 & 0.133 & 0.153 & 0.140 & 0.258 \\
\hline Path 6 & 0.302 & 0.197 & 0.198 & 0.188 & 0.193 & 0.200 & 0.193 & 0.307 \\
\hline Path 7 & 0.166 & 0.278 & 0.276 & 0.160 & 0.281 & 0.278 & 0.274 & 0.178 \\
\hline
\end{tabular}

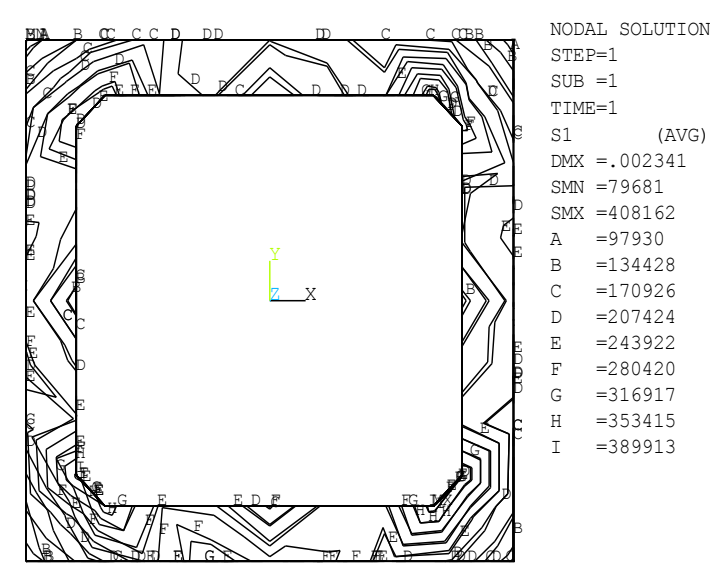

Figure 1. On 2-2 section the first main stress equivalent line chart $(\mathrm{Pa})$

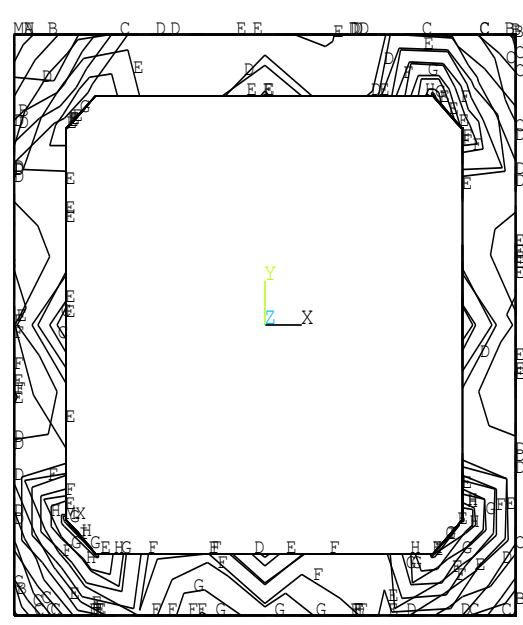

NODAL SOLUTION

\section{$\mathrm{STEP}=1$}

SUB $=1$

TIME $=1$

SY (AVG)

RSYS $=1$

$\mathrm{DMX}=.002341$

SMN $=42183$

$\mathrm{SMX}=406413$

$=62418$

$=102888$

$=143358$

$=183828$

$=224298$

$=264768$

$=305238$

$=345708$

$=386178$

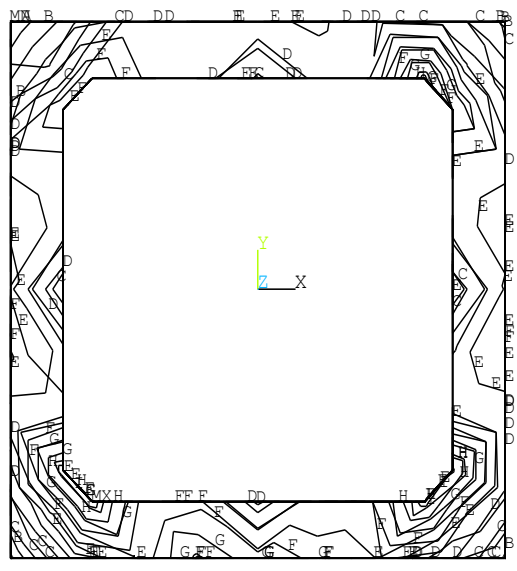

NODAL SOLUTION

$\mathrm{STEP}=1$

SUB $=1$

TIME $=1$

DMX $=.00234$

SMN $=43421$

SMX $=412696$

A $=63936$

$\begin{array}{ll}A & =63936 \\ B & =104967\end{array}$

C $=145997$

D $=187028$

E $\quad=228058$

$\mathrm{F} \quad=269089$

$\mathrm{G} \quad=310120$

$\begin{array}{ll}\mathrm{H} & =351150 \\ \mathrm{I} & =392181\end{array}$

Figure 2. On 3-3 section the first main stress equivalent line chart $(\mathrm{Pa})$

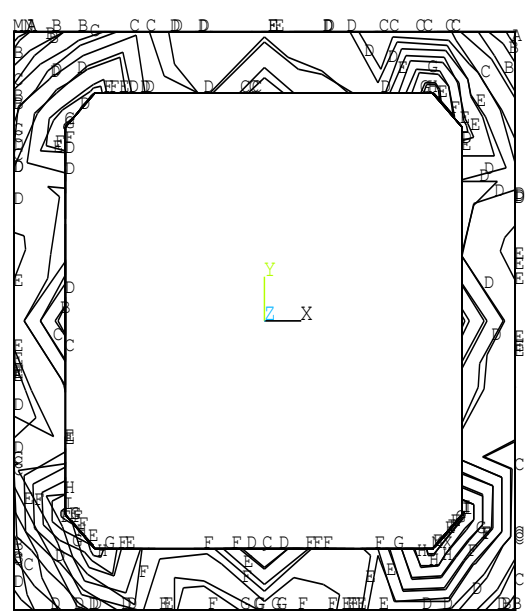

NODAL SOLUTION

$\mathrm{STEP}=1$

SUB $=1$

TIME $=1$

SY (AVG)

RSYS $=15$

DMX $=.002341$

SMN $=77679$

SMX $=394207$

$\mathrm{A}=95264$

B $=130434$

C $=165604$

D $=200773$

E $=235943$

$\mathrm{F}=271113$

G $=306283$

$\mathrm{H}=341453$

$=376622$
Figure 3. On 2-2 section the circumferential stress equivalent line chart $(\mathrm{m})$
Figure 4. On 3-3 section the circumferential stress equivalent line chart (m) 
B. Deformation Analysis

The vertical displacement's value of inverted siphon on the key points of each path is shown in Table 2 .
Vertical displacement of inverted siphon is shown in Fig.5 and Fig.6.

TABLE IIVERTICAL DISPLACEMENT VALUE OF EACH ROUTE ON THE KEY POINT（MM）

\begin{tabular}{|c|c|c|c|c|c|c|c|c|}
\hline \multirow{2}{*}{ location } & \multicolumn{9}{|c|}{ key point } \\
\cline { 2 - 9 } & $\mathbf{1}$ & $\mathbf{2}$ & $\mathbf{3}$ & $\mathbf{4}$ & $\mathbf{5}$ & $\mathbf{6}$ & $\mathbf{7}$ & $\mathbf{8}$ \\
\hline Path 1 & 2.314 & 2.314 & 2.314 & 2.312 & 2.314 & 2.314 & 2.313 & 2.312 \\
\hline Path 4 & 2.323 & 2.323 & 2.323 & 2.323 & 2.323 & 2.322 & 2.322 & 2.322 \\
\hline Path 7 & 2.339 & 2.338 & 2.338 & 2.341 & 2.338 & 2.337 & 2.338 & 2.339 \\
\hline
\end{tabular}

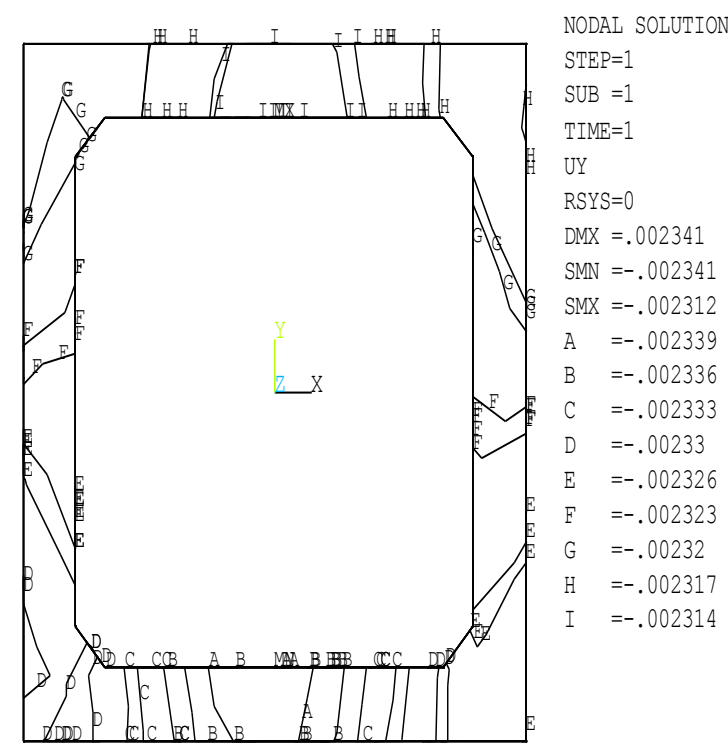

Figure 5. On 2-2 section the vertical displacement equivalent line

$$
\text { chart }(\mathrm{m})
$$

As can be seen from Table 2 and Fig.5 and Fig.6, the vertical displacement values of inverted siphon roof, side panels and on the floor almost is the same, indicating that the entire inverted siphon basically happens is rigid displacement, while the inverted siphon itself deformation is small. This is mainly due to the foundation of the inverted siphon pipe structure is relatively soft, and elastic modulus is much smaller than the modulus elasticity of concrete, so the inverted siphon appeared vertical rigid displacement.

\section{CONCLUDING REMARKS}

In summary, the big punch inverted siphon project used floating and sinking method of construction is economically reasonable. Through the inverted siphon stress and deformation analysis, it indicates that the inverted siphon can meet project requirements and is safety and reliability.

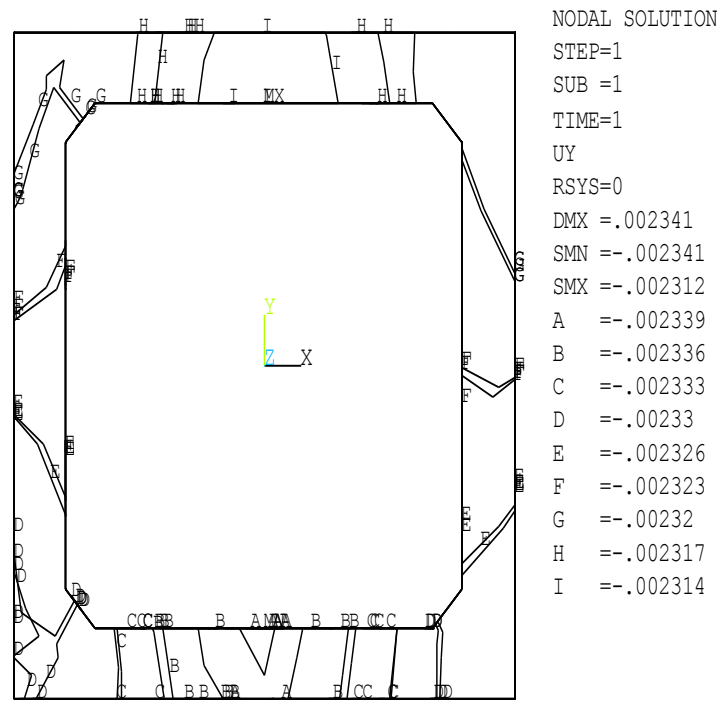

Figure 6. On 3-3 section the vertical displacement equivalent line

$$
\text { chart }(\mathrm{m})
$$

\section{REFERENCES}

[1] Hui-Fang Xue,You Wang. Self-Vibration Characteristics of Plane Gate in Inverted Siphon Project C]. Advances in Intelligent Structure and Vibration Control.2012:62-66.

[2] Yan, Yibo,Liu, Guoqiang,Wang, Changde et al. Discharge Error Analysis of Check Gate Combined with Inverted Siphon in a Canal Simulation System [C]. 2011 International Conference on Control, Automation and Systems Engineering. [v.1].2011:1-4.

[3] SL191-2008. Design Code for Hydraulic Concrete Structure[S]. China Water Conservancy and Hydropower Press, 2008.

[4] Lun-Yan Wang,Lei Guo. Analysis on Concrete's Measures for Qin river Inverted-Siphons in winter $[C]$. Proceedings of the third international conference on modelling and simulation. vol. 2, Modelling and simulation in engineering.2010:70-73.

[5] Guangxin Li. Advanced Soil Mechanics [M]. Tsinghua University Press, 2005.

[6] Wenliang Ma,Weifang Zou. Three-dimensional finite element analysis of trench-buried inverted siphon structure [C]. 2012 7th International Conference on System of Systems Engineering. $2012: 380-382$.

[7] Xucheng Wang. Finite Element Method [M]. Tsinghua University Press, 2003. 
[8] Cheng Zibing,Wang Feng,Yan Wei et al. Experimental study on inverted siphon channel in South-to-North water diversion project [C]. Advances in hydraulic physical modeling and field investigation technology.2011:685-689.
[9] Jianjing Jiang, Xinzheng Lu, Lieping Ye. Finite Element Analysis of Concrete Structures [M]. Tsinghua University Press, 2004.

[10] Huiying Li, Wenduo Tian, Haixin Yan. Inverted Siphons [M] China Water Conservancy and Hydropower Press, 2006. 